\title{
Comparison of Maximum Isometric Strength, Proprioceptive, Dynamic Balance, and Maximum Angle by Applying the Fascial Distortion Model to Chronic Ankle Instability Subjects
}

\author{
Jae Kwang Lee ${ }^{1}$, Chan Myeong Kim² \\ 'Denudeun Hospital, Daegu, Republic of Korea; ${ }^{2}$ Korea Safety Health Environment Foundation, Work Environment Health Center, Cheongju, \\ Republic of Korea
}

Purpose: The purpose of this study was to investigate the effects of the fascia distortion model (FDM), one of the fascia treatments, on unstable ankle subjects. This was done through the chronic ankle instability tool (CAIT) questionnaire on maximum isometric muscle strength, proprioception, dynamic balance, and maximum angle.

Methods: An experiment was conducted using the chronic ankle instability tool questionnaire on males and females in their twenties who suffered from ankle instability. Before the experiment, maximum isometric strength, proprioceptive, dynamic balance, and maximum angle were measured. The fascia distortion model was applied and then measurements were taken again to compare and analyze the changes. Analysis was carried out using the paired t-test.

Results: After applying the fascia distortion model, maximum isometric strength, proprioceptive, dynamic balance, and maximum angle significantly improved $(p<0.05)$.

Conclusion: This study found that the fascia distortion model method was effective in improving maximum isometric strength, proprioceptive, dynamic balance, and maximum angle. The results suggest that the fascia distortion model method is a new intervention that could be used for subjects with chronic ankle instability.

Keywords: Cumberland ankle instability tool, Chronic ankle instability, Fascial distortion model

\section{서 론}

만성 발목 불안정성의 최상의 치료적 중재에 대해 지금도 여러 논란 이 있지만, 발목 삠 이후 나타나는 발목 불안정성에 대해 회복과 예방 을 위해서는 발목관절 주변 근력 강화 훈련, 발목관절 가동범위 증가 가 시행해야 한다는 여러 연구가 보고되어 왔다.1,2 그러나 운동은 즉 각적인 효과를 나타내기에는 시간적으로 오래 걸려, 임상에서는 즉 각적인 중재방안이 필요하다. 즉각적인 반응을 나타내기 위해 테이 핑을 이용하여 통증감소 및 운동기능향상 등을 연구하는 것이 주류 를 이루었다. 하지만 근골격계 통증 및 운동 기능을 향상시키기 위한 방법으로는 근막치료가 효과적이라는 연구가 많다.

최근에는 근막을 단순히 세포나 근육주위를 둘러싸고 있는 막이 라는 개념에서 탈피하여 우리 몸 전신에 3차원적으로 연속적인 연결 을 통해 우리 몸을 지지하고 형성하는 연부조직의 개념으로 받아지
고 있으며, ${ }^{3}$ 근육의 제한된 움직임과 통증이 섬유화(fibrosis)를 일으 켜 근육 내부구조의 변화가 유발되면 근막이 딱딱해져 주위 구조물 사이에서 유착되게 된다. ${ }^{4}$ 또한 근막의 손상이 발생하면, 근약화 (weakness), 가동범위제한 등의 기능장애, 자율신경계 문제 등의 증상 을 나타낼 수 있고, ${ }^{5}$ 생리적 적응력이 낮아지게 되어 근막의 긴장도 가 증가되고, 긴장도는 다른 영역으로 전달되면서 통증, 기능제한, 외 상 등으로 나타나며 연속성과 유연성이 상실된다고 한다. ${ }^{6}$ 임상에서 는 글라스톤(graston), 폼롤러(foam roller), 근막도수치료(fascial manipulation), 자가 근막이완(self myofascial release, SMR)에 대한 선행 연 구가 많았으나, 근막변형모델(fascial distortion model, FDM)은 새로운 컨셉의 근막치료로써, 환자의 주관적 표현인 신체 언어(body language)를 분석하여 진단을 내리고, 치료사의 손으로 문제점을 해결 하는 기존의 정형도수 치료의 진단 개념과 다른 새로운 치료 방법이 다. ${ }^{7}$ Fink 등8의 연구에 의하면 유착성 관절주머니염 환자에게 근막변
Received Sep 15, 2021 Revised Oct 5, 2021

Accepted Oct 7, 2021

Corresponding author Chan Myeong Kim

E-mail ptkcm@naver.com
Copylight ( 2021 The Korean Society of Physical Therapy

This is an Open Access article distribute under the terms of the Creative Commons Attribution Non-commercial License (https:// creativecommons.org/license/by-nc/4.0.) which permits unrestricted non-commercial use, distribution, and reproduction in any medium, provided the original work is properly cited. 
형모델과 도수치료를 각각 적용하여 능동 벌림 각도를 측정한 결과 근막변형모델이 도수치료보다 더욱 더 빠른 효과를 보였다. Park과 $\mathrm{Kim}^{9}$ 의 연구에서도 발등굽힘 제한이 있는 환자에게 근막변형모델 과 폼롤러를 각각 적용하여 발등굽힘을 비교하였을 때 더 빠른 효과 가 있었다고 보고하였다. 또한 Richter ${ }^{10}$ 은 독일 국가 질병 관리 지침 (German national disease management guideline)에 따른 치료방법과 근막변형모델을 비교하여 급성 허리통증 치료를 비교한 결과, 근막 변형모델에서 효과가 더 빨리 나타나고 기능향상과 통증감소에 더 욱 효과적이라고 하였다.

이처럼 임상에서 여러 치료방법들과 비교를 하여 뛰어난 효과를 나타내고 있지만, 비교적 최신 치료 컨셉이라는 이유로 근막변형모델 의 효과를 검증한 양질의 연구가 부족하고, 근막변형모델을 이용하 여 관절 각도, 통증에 대한 연구는 많았으나 근막이 근력과 고유수 용성감각, 균형에 미치는 영향에 대한 연구는 없었다. ${ }^{10,11}$ 따라서 본 연 구는 chronic ankle instability tool (CAIT) 설문지를 통해 불안정성 발 목 대상자들에게 근막변형모델을 적용하여 최대 등척성 근력, 고유 수용성 감각, 동적균형, 관절가동범위의 변화를 알아보고, 만성 발목 불안정 환자들에게 근막변형모델이 새로운 중재 방법이 되는지 알아 보고자 하였다.

\section{연구 방법}

\section{1. 연구대상}

본 연구의 대상자들은 대구시에 소재한 D대학교 물리치료과에 재학 중인 성인 남녀 22명을 대상으로, Cumberland 발목 불안정성 도구를 이용하여 24점 이하인 대상자들을 선정하였다. ${ }^{2}$ 본 연구의 목적과 절차에 대한 설명회를 통하여 이를 충분히 숙지 시킨 후 자발적으로 참여하고자 하는 자들로 선정하였다(Table 1).

연구 대상자의 제외 기준은 다음과 같다. 첫째, 최근 마지막 부상 이 최소 3 개월 전 인자, 둘째, 최근 3 개월 동안 하퇴부상이 없는 자, 셋 째, 뇌진탕, 어지럼증의 소견이 없는 자로 선정하였고, 본 연구의 취지 와 내용을 충분히 숙지하고 헬싱키 선언의 윤리적 원칙에 따라 연구 참여에 자발적 동의를 한 자로 선정하였다.13

Table 1. Anthropometric data

$(n=22)$

\begin{tabular}{lc}
\hline Cariable & Total \\
\hline SEX & 22 \\
M & 12 \\
F & 10 \\
Age (yr) & $25.3 \pm 4.5$ \\
Height $(\mathrm{cm})$ & $168.1 \pm 7.7$ \\
Weight $(\mathrm{kg})$ & $63.2 \pm 11.7$ \\
\hline
\end{tabular}

Mean \pm standard deviation.

\section{2. 측정도구 및 방법}

\section{1) 최대 등척성 수축(maximum isometric strength)}

발등굽힘, 발바닥 굽힘 시 사용되는 근육의 최대 등척성 수축력을 측 정하기 위해 동력계(baseline hydraulic manual muscle testers, fabrication enterprises INC, USA)를 사용하였다. 발등굽힘, 발바닥굽힘에 대 응하는 반대 방향으로 저항을 주어 최대 등척성 수축(muscle voluntary isometric force, MVIF)을 시켜 그 힘을 $\mathrm{kg}$ 단위로 측정하였다. 측 정 각도는 능동적 최대 발바닥굽힘 $45^{\circ}$ 와 발등굽힘 $25^{\circ}$ 로 설정하였 다. 실험 대상자는 항중력 상태를 적용하기 위해 의자에 앉은 상태에 서 발등굽힘을 측정하였고, 발바닥굽힘을 측정하기 위해 엎드린 상 태에서 무릎을 굽히고 발바닥 굽힘을 측정하였다. 측정 간 엉덩관절 의 대상작용을 방지하기 위해 두 손은 가슴 위에 교차하게 올려놓고, 체간은 고정되도록 하였다. 실험에 앞서 각각 3 회의 연습을 하고 검사 에 대한 적응성을 향상시켰다. 또한 개별 각 속도 사이의 휴식시간은 1 분으로 설정하였다. ${ }^{14}$

\section{2) 능동적 감각재위치 검사(joint position sense test)}

관절위치 감각 검사로 고유수용성 감각을 측정한다. 동작 분석 장치 (motion biofeedback device, Relive, Korea)를 사용하였다. Relive는 관성 측정 장치로 지구의 자기장, 해수면을 이용하여 절대각도(absolute angle)를 출력한다. 두 센서들 사이의 각도를 출력하는데, 하나의 센서 에 대해서 다른 센서의 위치를 계산한 각도로 상대각도(relative angle) 를 측정 가능하다. 이 장비는 설정한 축 $(\mathrm{X}, \mathrm{Y}, \mathrm{Z})$ 에 대해 수직인 면에 서 나타나는 움직임을 계산한다. 수평 테이블에 무릎을 펴고 발목을 중립 위치로 만들고, 두 개 센서 중 첫 번째 센서는 발바닥에 부착하 고, 두 번째 센서는 수평 테이블에 올려놓는다. 발등굽힘 $10^{\circ}$, 발바닥 굽힘 $15^{\circ}$ 에서 각각 3 회씩 오차 각을 측정하여 그 평균값을 구하였다 (Figure 1). ${ }^{15}$

\section{3) 동적균형(Dynamic balance)}

동적균형을 평가하기 위해 변형된 Star excursion balance test (SEBT)를 사용하였다. 변형된 SEBT는 발목 불안정성을 가진 대상자들을 판정 하는데 매우 높은 신뢰도(ICC = 0.91)를 나타내고, 3 개의 선을 선별하 여 측정거리에 따라 안정성과 균형 능력이 증가 혹은 감소되었다고 판단할 수 있는 근거가 된다. ${ }^{16}$ 측정에 있어 바닥에 표시된 선을 사용 하게 되고, 각 방향에 대한 명칭은 시계 방향 순서로 첫 번째 앞쪽뻗 침(anterior, ANT), 두 번째 뒤안쪽뻗침(posterior-medial, PM), 세 번째 뒤가쪽뻗침(posterior-lateral, PL)이라 한다. ${ }^{17}$ 대상자는 정해진 위치에 뒤꿈치를 맞추고 서서 발이 떨어지지 않는 선에서 최대한 멀리 발을 뻗게하고, 측정자는 최대한 멀리 뻗은 발이 3 초 이상 유지되는 해당 지점을 줄자로 측정한다(Figure 2). 

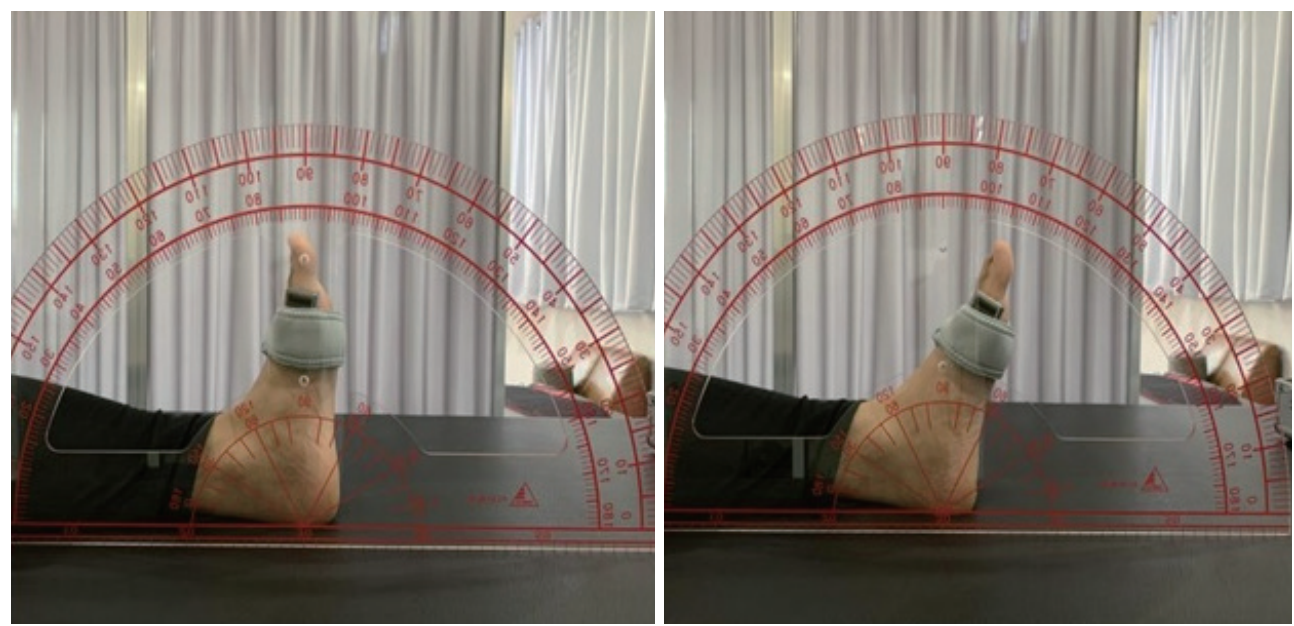

Figure 1. Joint position sense test.
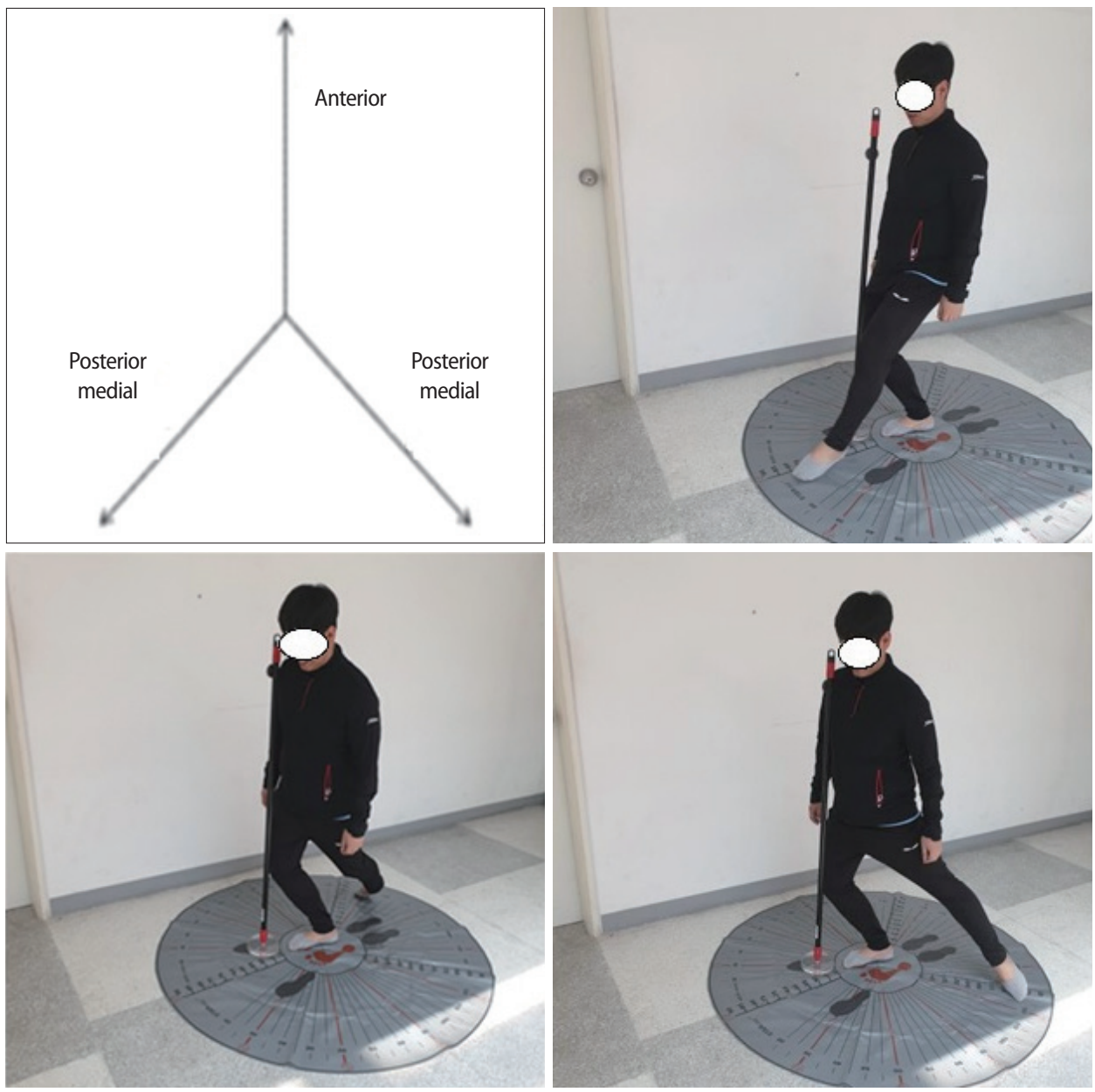

Figure 2. Dynamic balance.

\section{4) 최대 관절각도(Maximum angle)}

각도계를 사용하여 최대 관절각도를 측정하였다. 바로 앉은 자세에 서 무릎관절을 $90^{\circ}$ 굽힘하고, 가쪽 복사뼈를 축으로 하고, 고정팔을
종아리뼈 가쪽의 중심선과 평행하게 하였으며, 운동팔은 다섯 번째 발허리벼 가쪽의 중심선과 평행하게 하였다. 발등굽힘, 발바닥굽힘 의 최대 가동범위를 측정하였다. ${ }^{18}$ 


\section{3. 실험절차}

불안정한 발목의 최대 등척성 수축력, 고유수용성감각, 동적균형, 관 절최대각도를 근막변형모델을 적용하기 전과, 적용하고 난 후를 측 정하였다. 대상자의 수행 순서에 대한 영향을 없애기 위하여 근막변 형모델 적용 전에 10 분 동안의 휴식 시간을 주었다. 측정자는 블라인 드를 하였고, 정확한 측정을 위해 임상경력 8 년의 물리치료사의 의하 여 감독되었다.

\section{1) 근막변형모델(FDM)}

본 연구의 중재방법으로 적용된 근막변형모델치료는 아래와 같은 방 법으로 시행하였으며, 중재의 효과가 나타날 수 있도록 불안정한 발 목의 표현들에 맞게 근막변형모델치료를 적용하였으며, 연구의 신뢰 성을 높이기 위해 임상 경력 8년차 이상의 물리치료사가 중재하였고, 1 회만 실시하였다. 구체적인 방법은 다음과 같다.

(1) Trigger bands

(1) 정강뼈 앞쪽 부위(tibia anterior part)

정강뼈의 거치면에서 시작하여 정강뼈를 따라 2,3 번째 발가락까지 연결되는 선을 따라 엄지손가락을 이용하여 강한 압력을 주어 선의 주행방향과 일치하게 치료를 적용한다.

\section{(2) 종아리뼈 가쪽 부위(posterior lateral part)}

종아리뼈 머리의 약간 뒤쪽에서 시작하여 바깥 복사뼈 뒤쪽을 지나 5 번째 발가락까지 연결되는 선을 따라 엄지손가락을 이용하여 강한 압력을 주어 선의 주행방향과 일치하게 치료를 적용한다.

\section{(3) 종아리 뒤쪽 가운데 부위(posterior medial part)}

안쪽 다리오금에서 시작하여 안쪽 복사뼈 뒤쪽을 지나 1 번째 발가락 까지 연결되는 선을 따라 엄지손가락을 이용하여 강한 압력을 주어 선의 주행방향과 일치하게 치료를 적용한다.

\section{(2) Continuum distortion}

통증을 느끼는 관절주변의 조직에 녹는 듯 하는 느낌이 들 때까지 강 한 손가락 압력을 주기 위해 엄지손가락을 적용부위에 눌러서 10-15 초가량 치료를 적용한다(Figure 1). 정강뼈와 종아리뼈 말단부위, 바 깥복사뼈 주위 등에 주로 나타난다.

\section{(3) Cylinder distortion}

통증을 호소하는 부위를 손바닥 전체를 이용하여 강한 압박을 적용 하며 넓게(squeeze) 쓸어내린다(Figure 2).

\section{4. 자료 분석}

변수의 정규성 검증을 위해 Shaprio-Wilks 검정을 시행하였고, 그 결 과 정규성을 만족하여 대응표본 t검정(paired t-test)를 사용하여, 대상 자들의 등척성 최대 근력, 관절재위치, 동적균형, 최대 관절각도 측정 값의 전후를 비교하였다. 수집된 측정값의 분석은 SPSS Statistics ver$\operatorname{sion} 20.0$ 을 이용하였으며, 통계학적 유의수준을 검증하기 위하여 $\mathrm{p}<0.05$ 로 설정하였다.

\section{결 과}

\section{1. 연구대상자들의 일반적 특성}

본 연구에 참여한 대상자는 CAIT 불안정성을 진단받은 22명이 실험 에 참가하였다. 평균나이는 $25.3 \pm 4.5$ 세, 체중 $63.2 \pm 11.7 \mathrm{~kg}$ 그리고 신 장은 $168.1 \pm 7.7 \mathrm{~cm}$ 였다(Table 1$)$.

\section{2. 최대근력 분석}

발등굽힘 최대 등척성 실험 전 $12.77 \pm 2.75$ 에서 $18.27 \pm 6.88$ 로 통계학 적으로 유의한차이를 보였고 $(\mathrm{p}<0.05)$, 발바닥굽힘 최대 등척성은 실 험 전 $18.40 \pm 4.86$ 에서 $23.27 \pm 8.73$ 로 통계학적으로 유의한 차이를 보 였다 $(\mathrm{p}<0.05)($ Table 2).

\section{3. 관절재위치 분석}

발등굽힘 $10^{\circ}$ 는 $3.36 \pm 2.10$ 에서 $2.59 \pm 1.43$ 으로 통계학적으로 유의한

Table 2. Comparison before and after fascial distortion model intervention

\begin{tabular}{lcccc}
\hline & PRE & POST & $t$ & $p$ \\
\hline MIS & & & & \\
DFMIS & $12.77 \pm 2.75$ & $18.27 \pm 6.88$ & 3.295 & $<0.001^{*}$ \\
PFMIS & $18.40 \pm 4.86$ & $23.27 \pm 8.73$ & 2.519 & $0.020^{*}$ \\
JPST & & & & \\
DF 10 & $3.36 \pm 2.10$ & $2.59 \pm 1.43$ & 2.222 & $0.037^{*}$ \\
PF 15 & $4.68 \pm 3.98$ & $3.27 \pm 1.88$ & 2.341 & $0.029^{*}$ \\
DB & & & & \\
ANT & $81.95 \pm 5.68$ & $84.68 \pm 4.55$ & 2.400 & $0.026^{*}$ \\
PM & $81.40 \pm 10.36$ & $83.68 \pm 8.11$ & 2.202 & $0.039^{*}$ \\
PL & $85.77 \pm 11.53$ & $88.59 \pm 11.08$ & 2.222 & $0.037^{*}$ \\
MA & & & & \\
DFMA & $19.95 \pm 5.37$ & $24.68 \pm 5.57$ & 5.524 & $<0.001^{*}$ \\
PFMA & $52.95 \pm 10.12$ & $58.22 \pm 9.85$ & 4.143 & $<0.001^{*}$ \\
\hline
\end{tabular}

Mean \pm standard deviation.

MIS: maximum isometric strength, JPST: joint position sense test, DB: dynamic balance, MA: maximum angle, DFMIS: dorsi flexion maximum isometric strength, PFMIS: plantar flexion maximum isometric strength, DF $10^{\circ}$ : dorsi flexion $10^{\circ}, \mathrm{PF} 10^{\circ}$ : plantar flexion $15^{\circ}$, ANT: anterior direction, PM: posterior medial direction, PL: posterior lateral direction, DFMIA: dorsi flexion maximum angle, PFMIA: plantar flexion maximum angle. 
차이를 보였고 $(\mathrm{p}<0.05)$, 발바닥굽힘 $15^{\circ}$ 는 $4.68 \pm 3.98$ 에서 $3.27 \pm 1.88$ 로 통계학적으로 유의한 차이를 보였다 $(\mathrm{p}<0.05)$ (Table 2).

\section{4. 동적균형 분석}

앞쪽뼏침은 $81.95 \pm 5.68$ 에서 $84.68 \pm 4.55$ 로 통계학적으로 유의한 차이 를 보였고 $(\mathrm{p}<0.05)$, 뒤안쪽뻗침은 $81.40 \pm 10.36$ 에서 $83.68 \pm 8.11$ 로 통계 학적으로 유의한 차이를 보였으며 $(\mathrm{p}<0.05)$, 뒤가쪽뻗침은 $85.77 \pm 11.53$ 에서 $88.59 \pm 11.08$ 로 통계학적으로 유의한 차이를 보였다 $(\mathrm{p}<0.05)$ (Table 2).

\section{5. 관절 최대각도}

발등굽힘 최대 각도는 $19.95 \pm 5.37$ 에서 $24.68 \pm 5.57$ 로 통계학적으로 유 의한차이를 보였고 $(\mathrm{p}<0.05)$, 발바닥굽힘 최대 각도는 $52.95 \pm 10.12$ 에서 $58.22 \pm 9.85$ 로 통계학적으로 유의한 차이를 보였다 $(\mathrm{p}<0.05)$ (Table 2).

\section{고 찰}

근막변형모델의 이론에 의하면 인체에 가해지는 비정상적인 외력에 의해 급성손상이나 만성적인 장력으로 인한 근막의 뒤틀림, 분리, 꼬 임 등 여러 근막의 변형으로 인해 기능부전이나 통증의 증상이 유발 할 수 있다. 719 그로 인해 만성 발목 불안정인 사람들은 발목 근육의 근력 및 위치 감각의 결핍, 종아리근의 반응시간 감소, 균형능력, 발등 굽힘 가동범위의 감소가 발생하고, ${ }^{20} \mathrm{Kelli}$ 등 ${ }^{21}$ 은 빈번한 손상에 의한 근육의 약화는 발목관절의 기능적 움직임과 안정성을 약화시킨다고 보고하고 있다. 따라서 본 연구는 근막에 대한 관점으로 접근하여 근 막변형모델 치료를 적용하여 불안정성 발목의 근력, 고유수용성 감 각, 동적균형, 관절가동범위의 변화가 어떻게 나타나는지 알아보고 자하였다.

근막변형모델은 연부조직 가동술의 한 종류이며, 섬유증(fibrosis) 와 염증성 질환 치료에 적합한 방법으로써, 근막에 자극을 주면 기계 적수용기들(mechanoreceptors)이 반응하게 되고 근육수축에 관여하 는 $\mathrm{H}$ 반사를 억제하게 된다. ${ }^{22}$ 또한 수분 부족에 의한 점탄성이 떨어진 근막에 수분을 분산시켜 수축과 이완능력을 향상시켜준다. ${ }^{23}$ 이러한 생리적 특성들을 통해 통증을 감소시키고, 근막의 뒤틀림, 꼬임, 조직 을 재배열하며, 최종적으로는 기능적인 움직임을 증진시킨다. ${ }^{24} \mathrm{Park}^{25}$ 의 연구에서는 근막이완요법을 실시하면 운동신경전도와 감각신경 전도 검사에서 진폭과 신경전도속도는 증가하고 잠복기는 감소한다 고 하였으며, Mcleod 등 26 의 연구에서는 근막이완이 운동신경의 복 합근육활동을 향상시킨다고 하였다. 선행연구 결과를 통해 앞쪽뻗 침, 뒤안쪽뻗침, 뒤가쪽뻗침 모든 방향에 근막변형모델을 적용하였 기에 수축과 이완을 제한하는 근막에 물리적 압박을 통해 수분을 분
산시켜서 생리학적으로 적응하는 능력을 촉진시켰고 신경전도 속도 또한 증가되고 그 결과 스트레스를 줄이고, 근육을 더욱 효과적으로 움직일 수 있도록 운동신경의 복합근육활동을 향상시켜 발등굽힘, 발 바닥굽힘 모두 등척성 수축력이 유의하게 증가하였다고 사료된다 $(\mathrm{p}<$ 0.05).

고유수용성 감각의 변화를 알아보기 위해 대상자가 능동적으로 목표 각도를 재현하는 방법이 실시되었다. 발목 불안정성 대상자들 의 능동적 관절 위치감각은 발등 굽힘, 발바닥 굽힘 모두 안정성 발목 보다 유의하게 많은 차이를 나타났다 $(\mathrm{p}<0.05){ }^{15}$ 발목관절에 지속적 인 손상은 들신경(afferent nerve)에 영향을 미치고 발목 주변의 근육 약화와 손상된 관절낭 및 인대의 동심성 신경섬유의 기능 감소로 이 어져 발목 고유수용성 감각의 저하를 나타낸다고 보고하였다. ${ }^{28}$ 발목 불안정성 대상자들에게 근막변형모델을 적용하고 발등굽힘, 발바닥 굽힘의 관절 위치감각의 차이가 유의하게 감소하였다 $(\mathrm{p}<0.05)$. 발목 인대(ligament)나 관절낭(joint capsule)을 싸고 있는 근막에는 고유수 용성(proprioceptor)감각이 많이 존재하고, 이는 운동 시스템(motor system)에 움직임과 안정성에 매우 중요한 역할을 한다. ${ }^{29}$ 고유수용성 신경근 촉진법과 연부조직가동술의 비교 한 선행연구에서는 연부조 직가동술이 근막에 위치한 많은 수용기들을 직접적으로 자극하기 때문에 연부조직의 긴장을 감소시켜 근육기능을 향상시켜 발목관절 의 관절가동범위와 근력 및 동적안정성에 영향을 미친다고 하였다. ${ }^{30}$ 또한 고유수용성감각은 주동근과 길항근의 상대적 장력을 감지하 여 적절한 관절의 움직임이 나타나도록 하는데, 뒤넙다리근 이완을 통해 넙다리네갈래근 근력이 증가가 일어나는 근육의 길이-장력의 관계에 입각하여 tibia anterior $\mathrm{TB}$ 를 적용하고 발바닥 굽힘의 등척성 근력이 증가하였고, posterior medial, posterior lateral TB를 적용하여 발등 굽힘 등척성 근력이 증가한 결과와 함께, 관절 위치 감각의 오류 가 줄어드는 본 연구 결과에 의해 근막변형모델이 기계적 수용기를 촉진시켜 고유수용성감각에 영향을 미친다고 사료된다.

만성 발목 불안정인 사람들은 균형감각이 떨어져 최대 뻗기 과제 중 기저면을 더 가까이 유지하기 위해 정상 성인들보다 뻗기 거리가 유의하게 짧다고 하였다. ${ }^{31,32}$ 선행 연구에서도 CAIT 분류로 뻗기 과제 에서 앞쪽뻗침 방향으로 정상 성인과 불안정성 발목환자들 사이에 서 유의한 차이가 있다고 하였고, ${ }^{33}$ 앞쪽뻗침 방향은 발바닥 굽힘 최 대 근력과 높은 상관관계를 가진다고 하였다. ${ }^{34}$ 뒤안쪽뻗침과 뒤가쪽 뻗침방향은 엉덩관절의 근력과 상관이 있다는 연구가 보고되었는 데, ${ }^{35}$ 발목 불안정성을 가진 사람들은 발등 굽힘 감소가 되어 보행 중 안쪽번짐이 증가되고, 입각기 중간지지 단계에서 엉덩관절의 균형반 응이 감소한다고 하였다. ${ }^{36}$ 근막변형모델을 적용하여 발바닥 굽힘의 근력이 높아져서 앞쪽뻗침 방향으로 뻗기가 증가하였고 $(\mathrm{p}<0.05)$, 발등 굽힘이 증가 $(\mathrm{p}<0.05)$ 로 인해 엉덩관절의 근력에 영향을 줄 수 있어 뒤 
안쪽뻗침과, 뒤가쪽뻗침 방향으로의 뻗기가 증가하였다고 사료된다. 글라스톤과 폼롤러와 같이 근막 가동술 중 하나인 근막변형모델 은 운동 범위를 빠르게 개선하는 치료 기술로써 매우 높은 효율성을 나타내며, 근막변형모델 기법으로 먼쪽 노뼈 골절 환자를 치료하였 을 때 환자의 손목 가동범위와 손의 그립 강도가 즉각적으로 개선되 었다. ${ }^{37}$ Park과 $\mathrm{Kim}^{9}$ 의 연구에서도 발등굽힘에 근막변형모델이 폼롤 러와 발목스트레칭 보다 더욱 효과적이라고 하였다. $\mathrm{Kim}^{38}$ 연구에 의 하면 근막변형모델을 사용하였을 때 목과 어깨의 관절가동범위가 증가되었다. 본 연구에서도 발목 최대관절 각도에서는 근막변형모델 을 적용하고 발등굽힘과 발바닥 굽힘 모두 유의하게 각도가 증가하 였다 $(\mathrm{p}<0.05)$. 이는 근막에 압력이나 열이 적용되면 조직이 부드러워 지고 액체화되는 점탄성(viscoelasticity)이나 요변성(thixotrophy)를 이 용하여 교차결합에 강한 압박을 통해 변형되거나 유착된 근막을 이 완시켰고, ${ }^{719}$ 또 다른 근거로는 골지힘줄기관이 활성화되어 반사적인 운동뉴런을 억제시켜 근막이 이완되어 각도가 증가하였다. ${ }^{9}$

본 연구는 만성 발목 불안정증후군의 환자에게 근막변형모델 적 용이 근력과, 고유수용성감각, 동적균형, 최대관절각도에 어떤 영향 을 미치는지 알아보고자 하였다. 결과를 통해 근력과, 고유수용성감 각, 동적균형, 최대관절각도 모두에 영향을 줄 수 있는 치료방법으로 써 만성발목환자들에게 적용해 줄 수 있는 새로운 컨셉의 중재 방법 이 될 수 있을 것이라 사료된다.

제한점은 치료 효과가 얼마나 오랫동안 지속되는지 중재 후 사후 검증을 실시하지 않았다는 점이고, 다른 치료 방법과 비교를 하지 못 해 같은 치료시간 대비 얼마나 효율적인지 평가하지 못하였다. 추후 효과의 지속성에 대한 연구와 함께 다른 치료 방법과 비교를 통해치 료효과의 효율성에 대해 비교하는 연구가 필요 할 것이다.

\section{REFERENCES}

1. Kim KJ. Impact of combined muscle strength and proprioceptive exercises on functional ankle instability. J Int Acad Phys Ther Res. 2013;4 (2):600-4

2. Kim KJ, Heo M. Effects of virtual reality programs on balance in functional ankle instability. J Phys Ther Sci. 2015;27(10):3097-101.

3. Findley TW, Schleip R. Fascia research: basic science and implications for conventional and complementary health care. Munich, Elsevier Urban and Fischer, 2007:2-7.

4. Clay JH. Basic clinical massage therapy: integrating anatomy and treatment. Seoul, Yeong Mun Publishing Company, 2007:98-225.

5. Simons D. Travell J, Simons L. Myofascial pain and dysfucntion: the trigger point manual. Baltimore, Lippincott Williams\&Wilkins, 1999:12-9.

6. Ham YW. Myofascial release for muscle tension. J Allied Health. 1999; (8):15-25.

7. Typaldos S. FDM: clinical and theoretical application of the fascial Distortion Model within the practice of medicine and surgery. 4th ed. Kit- tery, Typaldos Publishing Co. 2002:3-60.

8. Fink M, Schiller J, Buhck H. Efficacy of a manual treatment method according to the fascial distortion model in the management of contracted ("Frozen") shoulder. Z Orthop Unfall. 2012;150(4):420-7.

9. Park S, Kim JY. Comparison of the effect of the fascial distortion model, foam rolling and self-stretching on the ankle dorsiflexion range of motion. J Kor Phys Ther. 2020;32(4):238-44.

10. Richter D, Karst M, Buhck H et al. Efficacy of fascial distortion model treatment for acute, nonspecific low-back pain in primary care: a prospective controlled trial. Altern Ther Health Med. 2017;23(5):24-32.

11. Thalhamer C. A fundamental critique of the fascial distortion model and its application in clinical practice. J Bodyw Mov Ther. 2018;22(1): 112-7.

12. Park EY, Kim WH. Different biomechanical characteristics in proprioception, muscle strenth, and time to peak torque at velocity of $300^{\circ} / \mathrm{sec}$ of the ankle joint in people with or without functional ankle instability. Phys Ther Korea. 2013;20(30):45-53.

13. Boyle J, Neques V. Joint position sense in the recurrently sprained ankle. Aust J Physiother. 1998;44(3):159-63.

14. Ji SU, Kim HS, Kwon GU et al. The ankle strength, balance and functional ability of the adolescent vollyball players with functional ankle instability. Korean J Phys Educ. 2004;43(1):567-77.

15. Chun SY, Choi OJ. The ankle joint position sense, strength and functional ability of the soccer player with functional ankle instability. Korean J Sport Sci. 2009;18(3):1119-30.

16. Bicici S, Karatas N, Baltaci G. Effect of athletic taping and kinesiotaping on measurements of functional performance in basketball players with chronic inversion ankle sprains. Int J Sports Phys Ther. 2012;7:154-66.

17. Kim DK, Lee SK. The effects of proprioceptive exercise training on dynamic postural stability and strength in female patient with functional ankle instability. The Kor J of Dance. 2015;73(5):1-12.

18. Eils E, Rosenbaum D. A multi-station proprioceptive exercise program in patients with ankle instability. Med Sci Sports Exerc. 2001;33(12): 1991-8.

19. Römer F. Practical manual of the fascial distortion model. FDM Shop. 2015:18-179

20. Hertel J. Functional instability following lateral ankle sprain. Sports Med. 2000;29(5):361-71.

21. Kelli R, Snyder, Todd A et al. Developing a framework for ankle function: a delphi study. J Athl Train. 2014;46(6):747-57.

22. Chaitow L. Research in the water and fascia: Micro-tornadoes, hydrogenated diamonds \& nanocrystals. Massage Today. 2009;9(6):17-21.

23. Lee WJ. Effect of fascial distortion model on the cobb's angle in adolescents with idiopathic scoliosis. J Kor Phys Ther. 2019;31(1):31-4.

24. Fowler S, Wilson JK, Sevier TL. Innovative approach for the treatment of cumulative trauma disorders. Work. 2000;15(1):9-14.

25. Park KH. Relaxation effect of myofascial release on muscle fatigue. Soongsil university. Dissertation of Doctorate Degree. 2012.

26. McLeod J. Nerve conduction measurements for clinical use. In: v Duijn H, Donker D, v Huffelen AC, eds, Current concepts in clinical neurophysiology, The hague, NV Drukkerij Trio, 1977:449-636.

27. Ghiasi F, Akbari A. Comparison of the effects of open and closed kinematic chain and different target position on the knee joint position sense. J Med Sci. 2007;7(6):969-76. 
28. Bowker S, Terada M, Thomas AC et al. Neural excitability and joint laxity in chronic ankle instability, coper, and control groups. J Athl Train. 2016; 51(4):336-43.

29. Wang H, Cochrane T. Mobility impairment, muscle imbalance, muscle weakness, scapular asymmetry and shoulder injury in elite volleyball athletes. J Sports Med Phys Fitness. 2001;41(3):403-10.

30. Baek HJ. The effects of instrument assisted soft tissue (IASTM) and proprioception neuromuscular facilitation (PNF) for range of motion, dynamic stability and fill, strength in the ankle joint. Cha University. Dissertation of Master's Degree. 2017.

31. Robinson R, Gribble P. Kinematic predictors of performance on the star excursion balance test. J Sport Rehab. 2008;17(4):347-57.

32. Gribble PA, Hertel J, Denegar CR. Chronic ankle instability and fatigue create proximal joint alterations during performance of the star excursion balance test. Int J Sports Med. 2007;28(03):236-42.

33. Lee JK. Comparison of stable and instable ankle by ankle instability tool. Catholic University of Daegu. Dissertation of Doctorate Degree. 2017.
34. Beak JK. Correlation between functional lower extremity instability on Ybalance test and muscle activity and functional movement of ankle. Biomedical Science of Korea University. Dissertation of Master's Degree. 2017.

35. Hubbard TJ, Kramer LC, Denegar CR et al. Correlations among multiple measures of functional and mechanical instability in subjects with chronic ankle instability. J Athl Train. 2007;42(3):361-6.

36. Yen S, Chui KK, Corkery MB et al. Hip-ankle coordination during gait in individuals with chronic ankle instability. Gait Posture. 2017;53:193200.

37. Teszner T, Zyluk A. Assessing the influence of FDM to the postoperative healing processes in distal fracture of the radius. Donau University. Dissertation of Master's Degree. 2011.

38. Kim MK. The effects of fascial distortion model on functions, disabilities and pain in patients with neck and shoulder pain. Catholic University of Daegu. Dissertation of Doctorate Degree. 2017. 